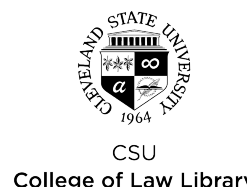

Cleveland State University

College of Law Library

\title{
EngagedScholarship@CSU
}

\section{A Tale of Two States: Territoriality and Minority Rights in Kosovo and Georgia}

\author{
Milena Sterio \\ Cleveland-Marshall College of Law, Cleveland State University, m.sterio@csuohio.edu
}

Follow this and additional works at: https://engagedscholarship.csuohio.edu/fac_articles

Part of the International Humanitarian Law Commons, and the International Law Commons How does access to this work benefit you? Let us know!

\section{Repository Citation}

Sterio, Milena, "A Tale of Two States: Territoriality and Minority Rights in Kosovo and Georgia" (2012). Law Faculty Articles and Essays. 1033.

https://engagedscholarship.csuohio.edu/fac_articles/1033

This Article is brought to you for free and open access by the Faculty Scholarship at EngagedScholarship@CSU. It has been accepted for inclusion in Law Faculty Articles and Essays by an authorized administrator of EngagedScholarship@CSU. For more information, please contact research.services@law.csuohio.edu. 


\section{A Tale of Two States: Territoriality and Minority Rights in Kosovo and Georgia}

\section{Milena Sterio*}

\section{Contents}

1. Introduction

2. Territoriality versus Minority Rights

2.1. Territorial Integrity

2.2. Minority Rights

2.3. History of Self-Determination

2.4. Recent Applications of Self-Determination Principles

3. Kosovo

4. Georgia (South Ossetia/Abkhazia)

5. Proposed Solution: Reconciling Territorial Integrity and Minority Rights in Kosovo and Georgia

5.1. Reconciling Kosovo with Georgia: A Political Difference?

5.2. Reconciling Territoriality with Minority Rights: A Proposed Solution

6. Conclusion

\section{Introduction}

Over the past decade, violent secessionist struggles have taken place in Kosovo and in South Ossetia and Abkhazia. Whereas Kosovo successfully declared independence from its mother State, Serbia, in 2008, South Ossetia and Abkhazia have officially remained an integral part of their mother State, Georgia. ${ }^{1}$ The two conflicts highlight the tension between the principle of territorial integrity on the one hand, and the need to protect minority rights on the other. Preserving the territorial integrity of mother States would lead toward denying remedial secession to struggling minority groups and arguably thereby refusing to respect minority rights. Allowing minorities to secede, in the goal of having their rights to self-determination fulfilled, would lead toward disrupting the territorial integrity of mother States. How can we reconcile the principle of territorial integrity with minority rights, and in particular, with the idea of self-determination - that every "people" ought to have a nation State?

\footnotetext{
* Assistant Professor of Law, Cleveland-Marshall College of Law. J.D., Cornell Law School \& Université Paris I-Panthéone-Sorbonne, summa cum laude; Master's Degree, Private International Law, Université Paris I-Panthéon-Sorbonne, cum laude. The author would like to thank the Cleveland-Marshall College of Law Library for outstanding research assistance.

$1 \quad$ See infra Parts 3 and 4.
} 
This article will argue that territoriality and minority rights can work in tandem, because most secessionist claims by minority groups involve claims to territory. Thus, territoriality and minority rights are both about land, and the relevant inquiry should be whether to alter the status quo, at the expense of a mother State's territory and in order to accommodate minority rights. This paper seeks to answer this difficult question in the context of recent secessionist struggles in Kosovo and in Georgia. Part 2 will discuss the principle of territorial integrity under international law, before turning to a discussion of minority rights, and in particular, the principle of self-determination. Part 3 will focus on Kosovo and will describe the recent war in this region, leading toward the Kosovar unilateral declaration of independence in 2008. Part 4 will similarly focus on Georgia, and will describe the recent conflicts in South Ossetia and Abkhazia. Part 5 will attempt to propose a reconciliation between territoriality and minority rights, by comparing the conflicts in Kosovo and Georgia, by arguing that the conflicts have produced different results because of politics, not because of law, and by outlining principles which could be relevant in examining future secessionist struggles. This article concludes that the international community should rely on objective legal criteria in judging the validity of secessionist struggles, rather than drawing conclusions based on political calculus.

\section{Territoriality versus Minority Rights}

The principles of territorial integrity of States and of minority rights may seem at odds in certain situations. If the need to respect minority rights rises to the level of secession - that is, if the minority group's rights are being abused by the mother State, or if the minority group no longer wishes to continue its existence within the mother State for other justifiable reasons - then respect for minority rights may trump the territorial integrity of the mother State. Conversely, if the territorial integrity of the mother State is preserved at all cost, this may at times lead toward a denial of protections and basic rights of the minority group. According to Lea Brilmayer, "[i]f ... territorial integrity takes priority, then minority groups within the existing state will be denied their cherished claims to independence". ${ }^{2}$ The two seemingly conflicting principles, territorial integrity and minority rights, will be examined in sections 2.1 and 2.2 below.

\subsection{Territorial Integrity}

The principle of territorial integrity is one of the basic tenets of international law; it is, according to Catherine Iorns, "a fundamental norm of the present world system of states and state sovereignty"."3

2 L. Brilmayer, 'Secession and Self-Determination: A Territorial Interpretation', 16 Yale J. Int'l L. (1991) p. 177, at p. 178.

3 Catherine J. Iorns, 'Indigeous Peoples and Self-Determination: Challenging State', 24 Case Western Reserve J. Int'l L. (1992) p. 199, at p. 330. 
Article 2 of the United Nations Charter reaffirms the primacy of States' territorial integrity by prohibiting States from using force against the territorial integrity of any other State. ${ }^{4}$ The same Article also stipulates that "[n]othing contained in the present Charter shall authorize the United Nations to intervene in matters which are essentially within the domestic jurisdiction of any state", unless the Security Council has effectively trumped State sovereignty through the exercise of its Chapter VII powers. ${ }^{5}$ A traditional interpretation of the phrase "within the domestic jurisdiction of any State" would posit that "domestic jurisdiction" translated into territorial borders. In other words, matters that are within a domestic jurisdiction of any State are almost always those that occur within the territory of that State. Thus, a State's territorial integrity is protected from outside interference by the United Nations or by any individual member State of the United Nations. It is only through intervention by the Security Council that a State's territorial integrity may be breached, under a traditional interpretation of the United Nations Charter. ${ }^{6}$

Moreover, territory is one of the basic requirements of statehood. According to the 1933 Montevideo Convention, an entity can achieve statehood if it fulfils four criteria: if it has a defined territory, a permanent population, a government, and the capacity to enter into international relations. ${ }^{7}$ Statehood is a legal theory that seeks to justify its attribution on objective criteria, which are at least in theory independent from the political reality underlying many attempts at the creation of a State-like entity through secession or separation. ${ }^{8}$ The requirement of territory is thus a basic criterion of the normative theory of statehood. A State cannot exist without a defined territory. Consequently, an attempt to disrupt State territory through the respect of minority rights via secession would violate the existing rules of State sovereignty.

4 Article 2(4) of the UN Charter states that "[a]ll Members shall refrain in their international relations from the threat or use of force against the territorial integrity or political independence of any state, or in any other manner inconsistent with the Purposes of the United Nations".

5 UN Charter, Article 2(7).

6 See e.g. P. Malanczuk, Akehurst's Modern Introduction to International Law, 7th edition (1996) pp. 306-309 (noting that the UN Charter outlaws "all uses of force against the territorial integrity or political independence of a state unless authorized by the Security Council or taken in self-defense".); see also T. Farer, "A Paradigm of Legitimate Intervention', in L. F. Damrosch (ed.), Enforcing Restraint: Collective Intervention in Internal Conflicts (1993) p. 316, at pp. 320-322 ("Article 2(4) prohibits force or the threat thereof against the political independence or territorial integrity of a state or for any other end inconsistent with the purposes and principles of the Charter.').

7 Montevideo Convention on the Rights and Duties of States, Article 1, 165 U.N.T.S. 19 (1933) (hereinafter "Montevideo Convention").

8 In fact, Article 3 of the Montevideo Convention states that " $[t]$ he political existence of the state is independent of recognition by the other states". Montevideo Convention, ibid., Article 3. 
The International Court of Justice (ICJ) has reaffirmed the principle of territorial integrity through its protection of the principle of sanctity of borders, or uti possidetis. In a case concerning a border dispute between Burkina Faso and Mali, two African States whose boundaries had been determined by their pre-independence colonial borders, the ICJ upheld the principle of uti possidetis. The ICJ stated that this was a general principle of international law, and that "[i]ts obvious purpose is to prevent the independence and stability of new States being endangered by fratricidal struggles provoked by the challenging of frontiers following the withdrawal of the administering power". 9 According to the Court, the principle of uti possidetis' essence "lies in its primary aim of securing respect for the territorial boundaries at the moment when independence is achieved". ${ }^{10}$ The Court recognized that the principle of uti possidetis may appear contradictory to the right of self-determination of peoples. However, the Court stated that the maintenance of the territorial status quo in Africa is the wisest solution to preserve those rights that the struggling peoples have already achieved, and to prevent further chaos. "The essential requirement of stability in order to survive, to develop and gradually to consolidate their independence in all fields, has induced African States judiciously to consent to the respecting of colonial frontiers, and to take account of it in the interpretation of the principle of self-determination of peoples."11 Under this holding of the ICJ, the principle of self-determination should be interpreted within the paradigm of the preservation of territorial status quo of existing States. In fact, African States had already adopted this view during decolonization in the 1960s. In 1964, the Organization of African Unity issued a decision which reaffirmed "respect for the sovereignty and territorial integrity of each State". ${ }^{12}$

The issue of borders and territorial integrity was recently debated during the dissolution of the former Yugoslavia. First, the Security Council and the European Community political bodies issued statements in 1991 reminding all parties to the conflict that changes to the existing borders (of the former Yugoslavia) could not occur by force. ${ }^{13}$ Then, in 1992, the Badinter Commission, a body of experts commissioned to answer difficult legal issues surrounding Yugoslavia's break-up, issued an opinion on the issue of borders between Serbia, Croatia, and Bosnia and Herzegovina. ${ }^{14}$ The Badinter Commission emphasized that, according to the ICJ ruling in the Brukina Faso v. Mali case, discussed above, the principle of uti possidetis is

9 Case Concerning the Frontier Dispute (Burkina Faso v. Mali), 1986 I.C.J. 554, para. 20 (Dec. 22).

10 Ibid., at para. 23.

11 Ibid., at para. 25.

12 O.A.U. Res. AGH/RES.16(I) (1964).

13 J. L. Dunoff et al., International Law: Norms, Actors, Process, 2nd edition (2006) at pp. 108-109.

14 Conference on Yugoslavia, Arbitration Commission Opinion No. 3, 31 I.L.M. 1499 (1992). 
recognized as a general principle of international law. ${ }^{15}$ Moreover, the Badinter Commission affirmed the existence of the principle of respect for the territorial status quo of existing borders, and concluded that "alteration of existing frontiers or boundaries by force is not capable of producing any legal effect". .6 According to the Badinter Commission, a secessionist claim to territory has no legal effect on the existing territorial borders. ${ }^{17}$ Thus, State territorial integrity trumps minority claims for separation and secession.

Despite the positive law on territorial integrity discussed above, scholars have argued that the existing system of borders and territory is morally arbitrary. ${ }^{18}$ According to some scholars, there are no true moral justifications for the international rule that upholds the territorial integrity of presently existing States. In fact, many present States acquired territory through the conquest of indigenous peoples, ${ }^{19}$ and many post-colonial State borders were created arbitrarily, through peace treaties among former colonizers. Thus, according to these scholars, one of the primary factors discussed within issues of minority rights and secession is the justification of territorial claims. "We must reinstate the human rights component of self-determination, and reinstate the belief that the state exists for the benefit of people, rather than the reverse."20

However, the above view is not uniform among courts, scholars and certainly not State governments. The current state of international law would uphold the principle of territorial integrity, and view any claim of protection of minority rights through secession with scepticism. ${ }^{21}$ Absent extra-ordinary circumstances, territorial integrity trumps a claim of secession by a minority group. The principle of selfdetermination for peoples, discussed below, leads toward remedial secession only in exceptional cases.

\subsection{Minority Rights}

Under modern-day international law, minority groups' rights are protected from abuse by their mother States, and are guaranteed the respect of basic rights. ${ }^{22}$ For

$15 \quad$ Ibid.

16 Ibid.

17 Ibid.

18 C. R. Beitz, Political Theory and International Relations (1979) pp. 136-143.

19 Iorns, supra note 2, at p. 338.

20 Ibid.

21 See e.g. D. Horowitz, 'A Right to Secede?', in S. Macedo and A. Buchanan (eds.), Secession and Self-Determination (2003) p. 50, at pp. 55, 59 ("Secession would not be a way of rectifying boundaries, because there are not truly natural land boundaries ... A secession or partition converts a domestic ethnic dispute into a more dangerous international one.") ("The support in international law for even a limited right to secede is very thin, indeed.").

22 On the status of minority rights generally, see D. Wippman, 'The Evolution and Implementation of Minority Rights', 66 Ford L. Rev. (1999) p. 597. 
example, Article 27 of the International Covenant on Civil and Political Rights provides that "[i]n those States in which ethnic, religious or linguistic minorities exist, persons belonging to such minorities shall not be denied the right ... to enjoy their own culture, to profess and practice their own religious, or to use their own language". ${ }^{23}$ The Human Rights Committee issued a general comment in 1994 focusing on Article 27, in which it concluded that States had positive obligations to protect minority rights. According to the Human Rights Committee, "[t]he protection of these rights is directed towards ensuring the survival and continued development of the cultural, religious and social identity of the minorities concerned". ${ }^{24}$ Moreover, minority rights are protected in the so-called "Copenhagen Document", an instrument prepared by the Conference (now Organization) on Security and Cooperation in Europe at a 1990 meeting in Copenhagen devoted to human rights. ${ }^{25}$ According to the Copenhagen Document, "[p]ersons belonging to national minorities have the right freely to express, preserve and develop their ethnic, cultural, linguistic or religious identity and to maintain and develop their culture in all its aspects, free of any attempts at assimilation against their will". ${ }^{26}$ Finally, minority rights are specifically protected in the Framework Convention for the Protection of National Minorities, a multilateral treaty resulting from the political commitments of States signatory to the Copenhagen Document. ${ }^{27}$ The Framework Convention guarantees to persons belonging to ethnic minorities the right to equal treatment before the law, as well as rights to use their language, to develop their culture and their identity, their religion, traditions and cultural heritage. ${ }^{28}$

In addition to minority rights that focus on the preservation of culture, tradition, language and religion, one of the basic forms of respect for minority rights is the claim for autonomy. The term "autonomy" generally underscores a form of political or governmental autonomy. "Generally, autonomy is understood to refer to independence of action on the internal or domestic level ...We regard autonomy as a relative term that describes the extent or degree of independence of a particular entity."29 Autonomy does not imply that a territory where the minority group lives must be independent from its mother State; rather, autonomy implies a form of self-government exercised by the minority group within the structure of the mother State ${ }^{30}$ The concept of autonomy is inherent in the infamous principle of self-determination, the idea that minority groups have a right to self-determine their political fate, despite

23 International Covenant on Civil and Political Rights, Article 27, 999 U.N.T.S. 171 (1966).

24 Human Rights Committee, General Comment 23, UN Doc. A/49/50 Vol. 1, at 108 (1994).

25 Document of the Copenhagen Meeting of the Conference on the Human Dimension of the CSCE, 29 I.L.M. 1305 (1990).

26 Ibid., at para. 32.

27 Framework Convention for the Protection of National Minorities, 34 I.L.M. 351 (1995).

28 Ibid., at Articles 4, 5 and 10.

29 H. Hannum and R. B. Lillich, 'The Concept of Autonomy in International Law', $74 \mathrm{Am}$. J. Int'l L. (1980) p. 858,

Ibid. 
the wishes of their mother State. This article, when discussing minority rights, will specifically focus on autonomy and the right to self-determination, and will, perhaps regrettably, leave a more thorough discussion on any other forms of minority rights to other academic endeavours.

The principle of self-determination has a long history and has been used and discussed throughout the 20th century. It has evolved to be a norm of customary law, and its contours represent a wide-ranging spectrum of alternatives for the minority group seeking to self-determine its fate. Thus, self-determination rights for a minority group may involve simply political and representative rights within a central State, on the one hand, or may amount to remedial secession and ultimately independence, on the other hand.

\subsection{History of Self-Determination}

Self-determination in international law is the legal right for a "people"31 or a minority group to attain a certain degree of autonomy from its sovereign. ${ }^{32}$ As early as 1918-1919, leaders like Vladimir Lenin and Woodrow Wilson advanced the philosophy of self-determination, the former based on violent secession to liberate people from bourgeois governments, and the latter based on the free will of people through democratic processes. ${ }^{33}$ Today, the principle of self-determination is embodied in

31 Although the term "people" is ambiguous and vague under international law, it typically refers to "people who live within the same state ... or people organized into a state". Z. Gruda, 'Some Key Principles for a Lasting Solution of the Status of Kosova: Uti Possedetis, 'The Ethnic Principle, and Self-Determination', 80 Chi-Kent L. Rev. (2005) p. 353 , at p. 367. Thus, "people" is a legal rather than natural category. Moreover, the term "people" has been purposely left undefined in international law, because if the right to self-determination were to be applied broadly to all conceivable groups, this could destabilise states and cause peace and security problems. B. S. Brown, Human Rights, Sovereignty, and the Final Status of Kosovo, 80 Chi.-Kent L. Rev. (2005) p. 235, at p. 249.

32 The principle of self-determination was first elevated to the international plane by President Woodrow Wilson, who included it in his infamous Fourteen Points. M. P. Scharf, 'Earned Sovereignty: Judicial Underpinnings', 31 Denv. J. Int'l L. \& Pol'y (2003) p. 373, at p. 378. For a full discussion of the principle of self-determination, see Gruda, supra note 31 , at pp. 369-382.

33 M. J. Kelly, 'Pulling at the Threads of Westphalia: "Involuntary Sovereignty Waiver"? Revolutionary International Legal Theory or Return to Rule by the Great Powers?', 10 UCLA J. Int'l \& For. Aff. (2005) p. 361, at pp. 387-388. 
multiple international treaties and conventions, ${ }^{34}$ and has crystallized into a rule of customary international law, binding on all States. ${ }^{35}$

Under the principle of self-determination, a group with a common identity and link to a defined territory is allowed to decide its political future in a democratic fashion. ${ }^{36}$ For a group to be entitled to exercise its collective right to self-determination, it must qualify as a "people". ${ }^{37}$ Traditionally, a two-part test has been applied to determine when a group qualifies as a people. ${ }^{38}$ The first prong of the test is objective and seeks to evaluate the group to determine to what extent its members "share a common racial background, ethnicity, language, religion, history, and cultural heritage", as well as "territorial integrity of the area the group is claiming". ${ }^{9}$ The second prong of the test is subjective and examines "the extent to which individuals within the group self-consciously perceive themselves collectively as a distinct 'people,' and "the degree to which the group can form a viable political entity".40

Self-determination of such groups that qualify as a people can be effectuated in different ways: through self-government, autonomy, free association or, in extreme cases, independence. Once the determination has been made that a specific group qualifies as a people and thus has the right to self-determination, the relevant inquiry becomes whether the right to self-determination creates a right to secession and

34 The term "self-determination" stems from Article 1 of the United Nations Charter, which speaks of the "principle of equal rights and self-determination of peoples". Subsequent declarations voted by the UN General Assembly also refer to the term "self-determination." See e.g. Declaration on the Granting of Independence to Colonial Countries and Peoples, G.A. Res. 1514 (1960) ("All peoples have the right to self-determination; by virtue of that right they freely determine their political status and freely pursue their economic, social and cultural development."); Declaration on Principles of International Law Concerning Friendly Relations and Co-operation Among States in Accordance with the Charter of the United Nations, G.A. Res. 2625 (1970) ("The establishment of a sovereign and independent State, the free association or integration with an independent State or the emergence into any other political status freely determined by a people constitutes modes of implementing the right of self-determination by that people.").

35 Scharf, supra note 32, at p. 378; Legal Consequences for States of the Continued Presence of South Africa in Namibia (South West Africa) Notwithstanding Security Council Resolution 276 (1970), 1971 I.C.J. 16, 31-32 (June 21); Western Sahara, 197 I.C.J. 12, 31-33 (Oct. 16): Concerning the Frontier Dispute (Burk. Faso v. Rep. of Mali), 1986 I.C.J. 554, 566-567 (Dec. 22); Concerning East Timor (Port. v. Austl.), 1995 I.C.J. 90, 265-268 (Jun. 30).

36 Scharf, supra note 32 , at p. 379.

37 Ibid.

38 Ibid. Note however that the term "people" has been purposely left undefined under international law and that the tests seeking to determine when a group qualifies as a people have been flexibly applied. See supra note 31 .

39 Scharf, supra note 32 , at p. 379.

40 Ibid. 
independence? ${ }^{41}$ In other words, as mentioned above, the right to self-determination can take different forms that are less intrusive on State sovereignty than secession is. ${ }^{42}$ Understandably, the international community views secession with suspicion, ${ }^{43}$ and traditionally the right to independence or secession as a mode of self-determination has only applied to people under colonial domination or some kind of oppression. ${ }^{44}$ However, the modern-day international law has come to embrace the right of non-colonial people to secede from an existing State, "when the group is collectively denied civil and political rights and subject to egregious abuses". ${ }^{45}$ This right has become known as the "remedial" right to secession, and has its origin in the infamous 1920 Aaland Islands case. ${ }^{46}$

The Aaland Islands were a small island group situated between Finland and Sweden, belonging administratively to the former and seeking to reunite with the latter ${ }^{47}$ In fact, the Aalanders claimed that they were ethnically Swedish, and that they wished to break off from Finland - which had just seceded from Russia - and to become a part of Sweden..$^{48}$ In an advisory opinion, the second Commission of Rapporteurs operating within the auspices of the League of Nations held first that this issue was properly of international, not domestic jurisdiction, and second that the Aalanders had a right to a cultural autonomy, which had to be exercised within

41 Secession under international law refers to separation of a portion of an existing State, whereby the separating entity either seeks to become a new State or to join yet another State, and whereby the original State remains in existence without the breaking off territory. Successful secessions around the globe have been rare, because secession seems inherently at odds with the principles of State sovereignty and territorial integrity, which have been core values of international law for centuries. See e.g. Horowitz, supra note 21, at p. 69 (citing James Crawford to conclude that State practice and international law show "the extreme reluctance of States to recognize or accept unilateral secession outside the colonial context".).

42 Scharf, supra note 32 , at p. 379.

43 Ibid., at p. 380 (noting that secession is "synonymous with the dismemberment of sates"). Note the 1970 statement by then UN Secretary-General U. Thant: "As far as the question of secession of a particular section of a State is concerned, the United Nations attitude is unequivocal. As an international organization, the United Nations has never accepted and does not accept and I do not believe it will ever accept the principle of secession of a part of its Member States." 'Secretary-General's Press Conferences', in 7 UN Monthly Chronicle 36 (Feb. 1970).

44 Scharf, supra note 32, at p. 380. Note that under this view the independence of a colony was not considered a secession, because that term referred only to the separation from a State of a portion of its domestic territory. Moreover, the international community has also leaned on the theory of "salt-water colonialism," under which self-determination only applied to lands separated from the metropolitan mother-state by oceans or seas.

45 Scharf, supra note 32 , at p. 381.

46 Ibid.

47 Dunoff et al., supra note 13, at pp. 118-119.

48 Ibid., at p. 119. 
Finland ${ }^{49}$ Only if Finland disrespected their ethnic and cultural autonomy would the Aalanders' right to separate from Finland be triggered. ${ }^{50}$

Similarly, the 1970 Declaration on Principles of International Law Concerning Friendly Relations preconditions the right of non-colonial people to separate from an existing State on the denial of the right to a democratic self-government by the mother State. ${ }^{51} \mathrm{~A}$ similar clause, striking a balance between the right to self-determination and territorial integrity, was inserted in the 1993 Vienna Declaration of the World Conference on Human Rights, accepted by all UN member States..$^{52}$ Other UN bodies have also referred to the right to remedial secession, such as the 1993 Report of the Rapporteur to the UN Sub-Commission Against the Discrimination and the Protection of Minorities on Possible Ways and Means of Facilitating the Peaceful and Constructive Solution of Problems Involving Minorities, ${ }^{53}$ and the General Rec-

49 The League of Nations created an International Committee of Jurists to determine whether the League of Nations had jurisdiction over this issue, and the Committee's report generally held that the League of Nations had such jurisdiction over this issue. Report of the International Committee of Jurists Entrusted by the Council of the League of Nations with the Task of Giving an Advisory Opinion upon the Legal Aspects of the Aaland Islands Question, League of Nations Official Journal, Special Supp. No. 3, at 5-10 (1920). Then, the League of Nations appointed a Commission of Rapporteurs to recommend a solution to the Aaland Islands problem, and the Rapporteurs report held that " $[\mathrm{t}] \mathrm{he}$ separation of a minority from the State of which it forms a part and its incorporation in another State can only be considered as an altogether exceptional solution, a last resort when the State lacks either the will or the power to enact and apply just and effective guarantees". The Aaland Islands Question: Report Submitted to the Council of the League of Nations by the Commission of Rapporteurs, League of Nations Doc. B7/21/68/106 (1921) (hereinafter "Aaland Islands Report").

50 Aaland Islands Report, ibid. (holding that "in the event that Finalnd ... refused to grant the Aaland population the guarantees which we have just detailed ... [t] he interests of the Aalanders ... would then force us to advise the separation of the islands from Finland").

51 "Nothing in the foregoing paragraphs shall be construed as authorizing or encouraging any action which would dismember or impair, totally or in part, the territorial integrity of political unity of sovereign and independent States conducting themselves in compliance with the principle of equal rights and self-determination of peoples as described above and thus possessed of a government representing the whole people belonging to the territory without distinction as to race, creed or color." G.A. Res. 2625, UN GAOR, 25th Sess., Supp. No. 28, at 121, UN Doc. A/8028 (1970).

52 Vienna Declaration and Programme of Action, World Conference on Human Rights, para. 2, UN doc. A/CONF.157/23 (1993), reprinted in 32 I.L.M. 1661 (1993). Note that the Vienna Declaration, unlike the 1970 Declaration on Friendly Relations, "did not confine the list of impermissible distinctions to those based on 'race, creed or color,' indicating that distinctions based on religion, ethnicity, language or other factors would also trigger the right to secede". Scharf, supra note 32, at p. 382.

53 Protection of Minorities: Possible Ways and Means of Facilitating the Peaceful and Constructive Solution of Problems Involving Minorities, Commission on Human Rights: 
ommendation XXI adopted in 1996 by the Committee on the Elimination of Racial Discrimination. ${ }^{54}$

The above documents demonstrate the reluctance of international law to accept the right to self-determination for minority groups, absent exceptional circumstances. And, as argued above, some scholars remain sceptical of the need to disrupt territorial integrity of mother States, even in such exceptional cases. ${ }^{55}$

\subsection{Recent Applications of Self-Determination Principles}

Most recently, the Canadian Supreme Court dealt with the right to self-determination regarding the proposed separation of Quebec from Canada.$^{56}$ Embracing the Aaland Islands precedent, the Canadian Supreme Court distinguished the right to internal self-determination from the right to external self-determination. ${ }^{57}$ While the former refers to a level of provincial autonomy within the existing State (Canada in this instance), including political, civic, cultural, religious and social rights, the latter refers to the right to separate from the existing State in order to form a new, independent State. ${ }^{58}$ The Canadian Supreme Court, like the League of Nations, held that a people has a right to internal self-determination first, and that only if that right is not respected by the mother State, the same people's right to break off may accrue. ${ }^{59}$ In other words, the right to separate is conditioned on the non-respect of the right to some form of provincial autonomy. ${ }^{60}$

Sub-commission on Prevention and Protection of Minorities, 45th Sess., Agenda Item 17, at para. 84, UN Doc. E/CN.4/Sub.2/1993/34 (1993).

54 Report of the Committee on the Elimination of Racial Discrimination, UN GAOR, 51st Sess., Supp. No. 18 at 125-126, para.11, UN Doc. A/51/18 (1996).

55 See e.g. Horowitz, supra note 21.

56 Reference re Secession of Quebec, [1998] 2 S.C.R. 217.

57 Ibid.

58 Ibid. (defining internal self-determination as "a people's pursuit of its political, economic, social and cultural development within the framework of an existing state", and defining external self-determination as potentially taking the form of secession, and as arising "in only the most extreme of cases ... under carefully defined circumstances"); see also Gruda, supra note 31, at pp. 380-381 (detailing the content of the right to external self-determination and of the right to internal self-determination).

59 Reference re Secession of Quebec, [1998] 2 S.C.R. 217 ("when a people is blocked from the meaningful exercise of its right to self-determination internally, it is entitled, as a last resort, to exercise it by secession...'). Note that the Canadian Supreme Court declined to answer the issue of under what circumstances such a right to secession accrues, as it determined that the population of Quebec is entitled to meaningful internal self-determination and thus not in a position to claim the right to external self-determination. Dunoff et al., supra note 13, at p. 222.

60 Reference re Secession of Quebec, [1998] 2 S.C.R. 217 (noting that when "the ability of a people to exercise its right to self-determination internally is somehow being totally frustrated", only then does the right to external self-determination accrue). 
Recent developments in international law may also lend credence to the idea that the right to remedial secession has crystallized as a norm. As an example, in the case of the former Yugoslavia, the republics of Slovenia, Croatia, Bosnia and Herzegovina, and Macedonia were entitled to secede because they had been denied the proper exercise of their right to democratic self-government, and, in some cases, had been subject to ethnic violence by the central government in Belgrade. ${ }^{61}$

These authorities suggest that if a government is at the high end of the scale of representative government, the only modes of self-determination that will be given international backing are those with minimal destabilizing effect and achieved by consent of all parties. If a government is extremely unrepresentative and abusive, then much more potentially destabilizing modes of self-government, including independence, may be recognized as legitimate. In the latter case, the secessionist group would be fully entitled to seek and receive external aid, and third-party states and organizations would have no duty to refrain from providing support. ${ }^{62}$

Recent examples of Kosovo and Georgia (South Ossetia and Abkhazia) shed more light on the debate over territorial integrity versus minority rights and will be discussed below. These examples demonstrate that the winner in the battle between territoriality and minority rights may depend entirely on the political will of the most powerful external States. This article argues that it is the support of the powerful super-States that seems to enable minority groups to secede from their mother State. Thus, although the right to remedial secession may have crystallized into a norm of customary law academically speaking, in practice, this right accrues only if there is sufficient political support for the people at stake.

\section{Kosovo}

Kosovo had been an autonomous province of Serbia, one of the six republics within the Socialist Federal Republic of Yugoslavia (SFRY) ${ }^{63}$ When the SFRY dissolved in the early 1990s, Kosovo remained a part of the SFRY successor, the Federal Republic of Yugoslavia (FRY) first, then a part of Serbia and Montenegro, and when Montenegro broke away from the latter, Kosovo remained a part of the sole Serbian State. ${ }^{64}$

Until the late 1980s, Kosovo had the status of an autonomous province within the SFRY and exercised important regional self-governance functions. ${ }^{65}$ More impor-

\section{Ibid.}

62 Scharf, supra note 32 , at p. 384

63 Brown, supra note 31, at p. 238.

64 Ibid., at pp. 238-240.

65 The 1974 SFRY Constitution granted Kosovo the status of an autonomous province within the country's federal structure. Gruda, supra note 31, at p. 387. Under the terms of the 1974 Constitution, Kosovo had the following rights: the right to adopt and change its Constitution; the right to adopt laws; the right to exercise constitutional judicial func- 
tantly, its predominantly ethnic Albanian population enjoyed multiple rights, such as the right to education in the Albanian language, the right to Albanian language media, the right to celebrate cultural holidays and to generally preserve its ethnic structure and belonging. ${ }^{66}$ However, in response to ethnic Albanian uprising movements throughout Kosovo, staged by guerrilla-like paramilitary groups, the Serbian leadership undertook draconian measures in the late 1980s to curb the upheaval. ${ }^{67}$ Thus, Kosovo's autonomous province status was removed, and the Albanian population was deprived of important civil and political rights. ${ }^{68}$

In 1999, when the former Serbian president Slobodan Milosevic engaged in a brutal tactic of oppression ${ }^{69}$ - once again in response to ethnic upheavals in Kosovo staged by the Kosovo Liberation Army (KLA), a separatist movement operating in Kosovo, ${ }^{70}$ the international community responded with force. ${ }^{71}$ North Atlantic Treaty Organization (NATO) countries launched a series of air strikes on the territory of Serbia, which ultimately forced Milosevic to sign a peace agreement with the Kosovars at Rambouillet, France, in June 1999. ${ }^{72}$ Under the terms of the Rambouillet

tions and to have a constitutional court; judicial autonomy and the right to a Supreme Court; the right to decide on changes of its territory; the right to ratify treaties that were concluded with foreign states and international bodies; the right to have independent organs and ministries within the local government.

66 H. H. Perritt Jr., 'Final Status for Kosovo', 80 3, Chi.-Kent L. Rev. (2005) p. 3, at p. 7 (noting that Kosovar Albanians were allowed to open an Albanian-language university in Pristina in 1969, and that the institutional changes under the 1974 SFRY Constitution resulted "in the growing Albanization of educational, political, and legal institutions".); see also Gruda, supra note 31, at p. 387.

67 Perritt, supra note 66, at p. 8 (describing the measures undertaken by Slobodan Milosevic beginning in 1989 to curb the Albanian upheaval).

68 Brown, supra note 31, at p. 263 (noting that amendments to Serbia's Constitution in 1989 and 1990 negated the Kosovar autonomy.).

69 Perritt, supra note 66, at p. 8 (describing the Serbian campaign of ethnic cleansing in Kosovo, accompanied by massive violence against the Kosovar Albanians by Serbian paramilitary, military and police forces).

70 P. R. Williams, 'Earned Sovereignty: The Road to Resolving the Conflict Over Kosovo's Final Status', 31 Denv. J. Int'l L. \& Pol'y (2003) p. 387, at p. 397 (noting that as a result of Serbian oppression, "some elements of the Kosovar Albanian population formed the Kosovo Liberation Army ("KLA"), which murdered members of the Serbian police and military forces and perceived Kosovar Albanian collaborators"); see also Perritt, supra note 66 , at p. 8 (noting that the KLA began attacking Serbian police and military facilities in Kosovo).

71 Perritt, supra note 66, at p. 8 (indicating that NATO began its bombing campaign "aimed at ending ethnic cleansing and protecting human rights in Kosovo"); see also I. King and W. Mason, Peace at Any Price: How the World Failed Kosovo (2006) pp. 43-45 (describing the events leading up to the NATO air strikes in the former Yugoslavia).

72 E. Hasani, 'Self-Determination Under the Terms of the 2002 Union Agreement Between Serbia and Montenegro: Tracing the Origins of Kosovo's Self-Determination', 80 Chi.Kent L. Rev. (2005) p. 305, at p. 320 (noting that the refusal of Serbia to agree to the 
Peace Agreement and subsequently United Nations Resolution 1244, Kosovo was to be administered by a United Nations (UN) provisional authority, the United Nations Mission in Kosovo (UNMIK), its safety was to be guarded by a NATO-led military force, KFOR, and subsequent negotiations were to take place in the near future, to decide about the true fate of the province. ${ }^{3}$

Once Milosevic stepped down as Serbia's president and leader, the Serbian outlook and its position toward the West changed. ${ }^{74}$ Under the Milosevic rule, Serbia largely ignored the West and leaned on its historical ally, Russia, for support. After Milosevic was ousted from power, Serbia turned toward the West. It became clear that in order to join Western Europe - and possibly become a member of the European Union (EU) - Serbia had to sacrifice Kosovo, or to at least refrain from using force in order to prevent it from breaking off. ${ }^{75}$ The relevant players, including the Serbian leadership, the Kosovar representatives, and UN and EU representatives, negotiated several times, but because of strong differences about the future of Kosovo, they were never able to reach consensus. ${ }^{76}$ In fact, Serbia, while pragmatically recognizing the need to accommodate Western demands, ${ }^{77}$ maintained its position that

Rambouillet Accords caused the NATO bombing campaign); see also Brown, supra note 31 , at p. 240.

73 See Interim Agreement for Peace and Self-Government in Kosovo, 23 February1999, UN Doc. S/1999/648 (7 June 1999), available at <www.state.gov/www/regions/eur/ ksvo_rambouillet_text.html>. [hereinafter "Rambouillet Accords"]. Moreover, Security Council Resolution 1244 directly references the Rambouillet Accords for the purpose of determining Kosovo's future status. S.C. Res. 1244, UN SCOR 54th Sess., 4011th mtg. ף11(e), UN Doc. S/RES/1244 (1999) [hereinafter "Resolution 1244"]. Thus, Resolution 1244 represents the legal foundation upon which "the civilian and military branches of the international administration in Kosovo are based". Hasani, supra note 14, at p. 323; see also Gruda, supra note 4, at p. 356. Under Resolution 1244, Kosovo was occupied by a multilateral force (KFOR) and administered by a United Nations Mission in Kosovo (UNMIK). For a detailed discussion of the UN administrative regime over Kosovo under the terms of the Rambouillet Agreement, see Hasani, supra note 72, at pp. 323-325.

74 Williams, supra note 70 , at p. 415 (describing the political changes in Serbia as a result of Milosevic's removal from office).

75 For example, during a recent trip to Serbia, in March 2008, I witnessed a peaceful political protest on the streets of Novi Sad, the capital of the northern province of Vojvodina, where protesters were carrying banners with signs reading: "We have a right to the European future" and "Don't let Kosovo slow us down". This demonstrates that a portion of the Serbian population seems aware of the necessity to let go of Kosovo in order to have access into Europe.

76 V. Trebicka, 'Recent Development: Lessons from the Kosovo Status Talks: On Humanitarian Intervention and Self-Determination', 32 Yale J. Int'l L. (2007) p. 255, at pp. 256-258 (describing the so-called status talks on the future of Kosovo and the fact that a "brokered political agreement ... has proven much more elusive than was first thought").

77 T. Garton Ash, 'This dependent independence is the least worst solution for Kosovo', The Guardian, 21 February 2008, available at <www.guardian.co.uk/world/208/feb/21/ 
Kosovo remain a territorial part of Serbia with strong regional autonomy. ${ }^{78}$ Kosovo, on the other hand, insisted that it deserved independence. ${ }^{79}$

On 17 February 2008, backed by powerful world countries like the United States, the United Kingdom and France, the Kosovar Parliament voted for a declaration of independence. ${ }^{80}$ In the few days following the Kosovar declaration of independence, the United States, as well as about $20 \mathrm{EU}$ countries formally recognized Kosovo as a new State. ${ }^{81}$ The recognition of Kosovo as a new State demonstrated the willingness of recognizing nations to respect minority rights by Kosovars at the expense of the Serbian territorial integrity. As will be discussed below, this was not the case in Georgia (South Ossetia and Abkhazia), where most of the Western powers refuse to accept independence by the secessionist provinces at the expense of Georgian territorial integrity. ${ }^{82}$

In October 2008, the United Nations General Assembly adopted a resolution requesting an advisory opinion from the ICJ on the issue of the Kosovar declaration of independence. ${ }^{83}$ More specifically, the Court was asked to opine on the legality of the unilateral declaration of independence by the provisional government of Kosovo, under international law. ${ }^{84}$ The ICJ responded in the affirmative: that the unilateral

kosovo> (comparing the loss of Kosovo for Serbia as a loss of a "gangrenous arm" and concluding that this is a "precondition of recovery").

78 In fact, the day after the Kosovar declaration of independence, the Serbian President, Boris Tadic, appealed to the UN Security Council to declare Kosovo's "unilateral and illegal" declaration of independence "null and void," because Kosovo's separation violates Security Council Resolution 1244 which reaffirms Serbia's sovereignty and territorial integrity. UNMIK News Coverage, 'Ban $\mathrm{Ki}$-moon urges restraint by all sides after Kosovo declares independence', 18 February 2008, available at: <www.unmikonline. $\mathrm{org} /$ news.htm $>$ (last visited on 12 May 2008).

79 Trebicka, supra note 76, at p. 255 (observing that the Kosovar Albanians have demanded their right to self-determination, which would lead to secession).

80 MSNBC, 'Kosovo Declares Independence from Serbia', 18 February 2008, available at <www.msnbc.msn.com/id/23203607> (last visited 3 June 2008).

81 For example, as of 18 February 2008, the United States, the United Kingdom, France and Belgium had all expressed support for the "new state of Kosovo". Ibid. Note however, that several States expressed their opposition to the Kosovar independence, including Spain, Russia, China, Indonesia, and Sri Lanka. N. Kulish and C. J. Chivers, 'Kosovo is Recognized but Rebuked by Others', The New York Times, available at <www.nytimes. com/2008/02/19/world/europe/19kosovo.html> (19 February 2008) (last visited on 12 May 2008).

82 See infra Part 4.

83 B. M. J. Szewczyk, 'Lawfulness of Kosovo's Declaration of Independence', 14:26 ASIL Insight (17 August 2010), available at <www.asil.org >.

84 Ibid. 


\section{Milena Sterio}

declaration of independence was legal, as it was not prohibited by any rule of general or specialized international law. ${ }^{85}$

The Court, however, failed to address the most difficult issue raised by the Kosovar separation from Serbia: whether Kosovo's independence was justified under the international law principle of remedial self-determination. The Court did discuss the principle of territorial integrity. In fact, during this politically contentious case, different States presented opposing arguments to the Court on the tension between territorial integrity and self-determination. ${ }^{86}$ Serbia and its allies argued that the principle of territorial integrity, enshrined in Article 2(4) of the United Nations Charter, prohibited unilateral declarations of independence ${ }^{87}$ Kosovo and its supporters, on the other hand, argued that the principle of territorial integrity only applied to States, in their relations, and did not apply to non-State actors, such as the Kosovar authors of the declaration of independence. ${ }^{88}$ The Court agreed with Kosovo and held that the principle of territorial integrity was confined to the sphere of inter-State relations, and that declarations of independence are questions of fact and power rather than law. ${ }^{89}$ Thus, the Court distinguished between the principle of territorial integrity, which is a question of law and applies to all States in their relations, and declarations of independence, which are non-legal factual occurrences. ${ }^{90}$

Moreover, the Court regrettably failed to opine on the legality of the declaration of independence within the context of Security Council Resolution 1244. The Resolution affirmed a commitment to "sovereignty and territorial integrity of the Federal Republic of Yugoslavia and the other States of the region". ${ }^{91}$ Thus, Serbia argued that the declaration of independence was inconsistent with Resolution 1244, as it inherently violated the territorial integrity of the Federal Republic of Yugoslavia. ${ }^{92}$ The ICJ, in what one of the dissenting judges labelled as a "post-hoc intellectual construct", refused to adopt this approach and ruled instead that the authors of the declaration of independence were not bound by Resolution $1244 .{ }^{93}$ Thus, the ICJ passed up the opportunity to contribute toward resolving the tension between territoriality and self-determination under international law. Judge Cançado-Trinidad argued in a lengthy separate opinion that international law does provide guidance on the legality of declarations of independence, and scholars have observed that the Court could have taken up the opportunity to distinguish between the case of Kosovo

85 See Accordance with International Law of the Unilateral Declaration of Independence, I.C.J. REPORTS 2010 (hereinafter "Accordance with International Law").

86 Szewczyk, supra note 83.

87 Ibid.

88 Ibid.

89 Accordance with International Law, supra note 85, at para. 79.

90 Ibid., at paras. 79-80.

91 S.C. Res. 1244, UN Doc. S/RES/1244 (10 June 1999), Annex 1, 6th princ.; Annex 2, 18.

92 Szewczyk, supra note 83.

93 See Accordance with International Law, supra note 85 (Declaration of Vice-President Tomka, at 3, ๆ 12). 
and other unsuccessful cases of attempted secession. ${ }^{94}$ "Indeed, there are strong reasons to distinguish Kosovo's declaration of independence from, for instance, that of South Ossetia or Abkhazia. Remedial secession may be lawful as the only possible means to safeguard fundamental human rights so as to maximize values of human dignity, but does not justify all territorial fragmentation."95

Is there a legal argument that separates Kosovo from South Ossetia or Abkhazia, as some have suggested, or is the sole difference in the political context underlying the two cases? Before attempting to answer this difficult question, this article will first address the situation in South Ossetia and Abkhazia.

\section{Georgia (South Ossetia/Abkhazia)}

South Ossetia is an autonomous administrative district of Georgia, and Abkhazia is an autonomous republic also within Georgia. ${ }^{96}$ These two provinces have functioned as de facto States in recent years, and have spurred international controversy during the summer of 2008, when Russia decided to support the two provinces by sending military troops to Georgia. ${ }^{97}$ The Russian intervention evolved into war between Georgia on one side and Russia, South Ossetia and Abkhazia on the other.

In August 2008, when the Georgian armed forces pushed into South Ossetia, Russia accused Georgia of genocide, claiming that thousands of South Ossetian civilians were killed by the Georgian troops. ${ }^{98}$ In response, Russia sent additional troops into South Ossetia and launched air strikes on Georgian territory ${ }^{99}$ After a few days of heavy fighting, Georgian troops were ejected from South Ossetia. ${ }^{100}$ Meanwhile, the Russian military troops stationed in Abkhazia began marching into Georgia; this advance into Georgia was accompanied by reports of widespread looting, burn-

94 See Szewczyk, supra note 83 (arguing that the ICJ passed up the opportunity to rule on the more difficult issue of self-determination and territoriality); see Accordance with International Law, supra note 85 (separate opinion of Judge Cançado Trinidade, at 71, १(ๆ 239-240).

95 Szewczyk, supra note 83.

96 See N. Pavlov, 'Russia, Georgia Seek Control of South Ossetia Capital', Reuters, 8 August 2008, <www.reuters.com/article/worldNews/idUSL768040420080808?pageNu mber $=2$ \&virtualBrandChannel $\Rightarrow$; see also 1 Council of the European Union, Indep. Int'l Fact-Finding Mission on the Conflict in Georg (2009) at 7, 17, available at <www. ceiig.ch>.

97 See ibid.; see also 1 Council of the European Union, ibid., at 13.

98 T. Parfitt, 'Russia Exaggerating South Ossetian Death Toll, Says Human Rights Group', Guardian, 13 August 2008, <www.ugardian.co.uk/world/2008/aug/13/geogia>; see also 1 Council of the European Union, supra note 96, at 10, 21.

99 See M. Barabanov, 'The August War Between Russia and Georgia', Moscow Defense Brief, \# 3, 2008, <www.mdb.cast.ru/mdb/3-2008/item3/articlel>; see also 1 Council of the European Union, supra note 96, at 10.

100 See Barabanov, supra note 99; see also 1 Council of the European Union, supra note 96, at $10-11$. 


\section{Milena Sterio}

ing and killing of civilians by Ossetian militia. ${ }^{101}$ On August 12, the Russian president ordered a halt to Russian military operations in Georgia, and a peace plan was brokered by the European Union (the so-called "Medvedev-Sarkozy peace plan"), which Russia, Georgia as well as the South Ossetian and Abkhazian separatist leaders signed and endorsed. ${ }^{102}$

Yet, Russia has refused to withdraw its military troops from Georgia. Russia has also signalled no intention to end its military presence in the disputed Georgian regions of Abkhazia and South Ossetia. ${ }^{103}$ In fact on 25 August 2008, Russia recognized these as independent States. ${ }^{104}$ Russia now says that its troops stationed in Abkhazia and South Ossetia are guests of the newly-born nations, and their status is not regulated by the Medvedev-Sarkozy peace plan. ${ }^{105}$

Currently, the status of South Ossetia is being negotiated between the central government of Georgia and the Russian-supported separatist government of South Ossetia. ${ }^{106}$ Recently, these negotiations have broken down in light of Russia's decision to reinforce the region militarily and give Russian passports to South Ossetians. ${ }^{107}$ The government of Georgia has expressed that it views these moves as attempts by Russia to annex the region effectively. ${ }^{108}$ The Georgian government levels the same criticism against Russian involvement in Abkhazia, which currently remains

101 L. Harding and J. Meikle, 'Georgian Villages Burned and Looted as Russian Tanks Advance', Guardian, 13 August 2008, <www.guardian.co.uk/world/2008/aug/13/georgia.russia6>; see also 1 Council of the European Union, supra note 96, at 27.

102 See A. E. Kramer, 'A French-Brokered Peace Offers Russia a Rationale to Advance', N.Y. Times, 14 August 2008, at A1 (explaining the points of the peace agreement). But see 1 Council of the European Union, supra note 96, at 22 (noting that while a ceasefire was being negotiated, the Russian and South Ossetian forces continued their military advances and occupied additional territories).

103 See Kramer, supra note 102.

104 See G. L. White and J. W. Miller, 'Russia Raises Ante on Separatist Georgia Regions', Wall St. Journal 26 August 2008, at A9; 1 Council of the European Union, supra note 96, at 37 (explaining that the recognition of the two provinces by Russia hinders any possible resolution of this problem). In addition to Russia, Nicaragua and Venezuela are the only two other countries that recognise South Ossetia and Abkhazia as States. G. Dubinsky, 'The Exceptions that Disprove the Rule? The Impact of Abkhazia and South Ossetia on Exceptions to the Sovereignty Principle', 34 Yale J. Int'l L. (2009) p. 241, at p. 241.

105 See generally Kramer, supra note 102 (indicating that Russia has defined its presence in the region as a peacekeeping measure); 1 Council of the European Union, supra note 96, at 188-189 (noting the Russian viewpoint: that its troops in the region have always been peacekeepers and that its military action in the region was in self-defense of such peacekeepers).

106 See White and Miller, supra note 104, at A11.

107 See D. McElroy, 'South Ossetian Police Tell Georgians to Take a Russian Passport, or Leave Their Homes', Daily Telegraph, 30 August 2008, at p. 17.

Ibid. 
a province of Georgia, but which operates as a de facto State. ${ }^{109}$ For example, like in South Ossetia, Russia has offered Russian passports to ethnic Abkhazians, and the Russian rouble has become the de facto currency in Abkhazia. ${ }^{110}$ The Abkhazian government concluded a series of agreements with Russia, accepting the establishment of a Russian military base in Abkhazia and offering other military advantages to Russia within the Abkhazian territory. Thus, like in South Ossetia, Russia maintains a strong political and military presence in Abkhazia. ${ }^{111}$

Most of the Western powers have expressed their support of Georgia and have refused to recognise the independence plight of South Ossetia and Abkhazia. ${ }^{112}$ Despite strong secessionist movements in these two regions, the European Union, NATO and the Organization for Security and Co-operation in Europe have refused to recognize South Ossetia and Abkhazia as independent entities, and have repeatedly stated that any such attempt at independence would violate the territorial integrity of Georgia, their mother State. The United States has also refused to recognise the legitimacy of these secessionist movements, and former US envoy and renowned diplomat Richard Holbrooke stated that the conflict could encourage other separatist movements in Russia. ${ }^{113}$

Within the context of the South Ossetian and Abkhazian struggles for remedial secession, most of the Western superpowers have emphasised the need to respect Georgian sovereignty and territorial integrity. When South Ossetians held a referendum in November 2006, at which time the ethnic South Ossetians and Russians living in the province nearly unanimously opted for independence from Georgia, both the Georgian central government as well as European authorities rejected the results and instead urged parties to re-engage in negotiations. ${ }^{14}$ In early 2000 , thenUN Special Representative of the Secretary General Dieter Boden and the Group of Friends of Georgia, consisting of the representatives of Russia, the United States, Britain, France and Germany, drafted a document outlining a possible distribution of competencies between the Abkhaz and Georgian authorities, based on a core

109 See e.g. 'West Condemns Russia Over Georgia', BBC NEWS, 26 August 2008, <news. bbc.co.uk/2/hi/europe/7583164.stm>.

110 I. Khashig, 'Abkhaz Rush for Russian Passports', Institute for War and Peace Reporting, 21 February 2005, <iwpr.net/report-news/abkhaz-rush-russian-passports>.

111 'Russia's build-up in the Black Sea', The Palestine Telegraph, 6 September 2009, <www. paltelegraph.com/world/asia-news/2139-russias-build-up-in-the-black-sea>.

112 See e.g. M. Sterio, 'On the Right to External Self-Determination: "Selfistans," Secession, and the Great Powers' Rule', 19 Minn. J. Int'l L. (2010) p. 137.

113 AP, 'Russia support for separatists could have ripples', NY Times, 31 August 2008.

114 CNN, 'S. Ossetia: 99\% Back Independence', 13 November 2006; CoE Information Office-Tbilisi, 'Council of Europe Secretary General calls for talks instead of "referendum" in the Georgian region of South Ossetia', 13 September 2006, available at <portal. coe.ge/enews/EEVIEuyFElfTRjjwgP.php> (last visited on 3 May 2011). 
respect for Georgian territorial integrity. ${ }^{115}$ Moreover, at the annual Organization for Security and Co-operation in Europe Parliamentary Assembly meeting in July 2008, the Assembly passed a resolution expressing concern over Russia's recent moves in breakaway Abkhazia. ${ }^{116}$ The resolution called on the Russian authorities to refrain from maintaining ties with the breakaway regions "in any manner that would constitute a challenge to the sovereignty of Georgia" and also urged Russia "to abide by OSCE standards and generally accepted international norms with respect to the threat or use of force to resolve conflicts in relations with other participating States". ${ }^{117}$ Finally, the United Nations has reaffirmed "the commitment of all Member States to the sovereignty, independence and territorial integrity of Georgia within its internationally recognized borders". 118

Kosovo achieved independence through a secessionist struggle at the expense of the territorial integrity of Serbia. South Ossetia and Abkhazia have not been able to do so. What is different in the two cases, and more importantly can the tension between territoriality and minority rights be resolved by studying each of these cases? This issue will be explored below.

\section{Proposed Solution: Reconciling Territorial Integrity and Minority Rights in Kosovo and Georgia}

Kosovo represents an example of a successful secessionist struggle. To the contrary, South Ossetia and Abkhazia illustrate examples of unsuccessful self-determination struggles, where a minority group is unable to achieve independence because of the primacy of the mother State's territorial integrity. First, how can the two cases be reconciled (section 5.1)? Second, how can the respect for territorial integrity of the mother State be reconciled with the need to protect minority rights, and what conclusions can one draw from the examples of Kosovo and Georgia (section 5.2)?

\subsection{Reconciling Kosovo with Georgia: A Political Difference?}

The South Ossetian and Russian leadership has relied on the Kosovo precedent to argue for secession and independence from Georgia. In fact, the South Ossetian leader has recently expressed his frustration at this lack of support by the Western powers, by complaining that his country has not been able to become independent although it has a better legal case for independence than Kosovo, which did become independent. ${ }^{119}$ Moreover, following Kosovo's declaration of independence the Rus-

115 US Department of State, Bureau of European and Eurasian Affairs, 'The Abkhazia Conflict', 28 July 2005.

116 Civil Georgia, 'OSCE PA Concerned Over Russian Moves’, 3 July 2008.

117 Ibid.

118 S. C. Res. 1808, UN Doc S/2008/1808 (15 April 2008).

119 'Bush Warns Moscow Over Breakaway Autonomy', CNN.com, 25 August 2008, <www. cnn.com/2008/WORLD/europe/08/25/russia.vote/index.html> ("We have more political-legal grounds than Kosovo to have our independence recognized ...”). 
sian Parliament released a joint statement reading: "Now that the situation in Kosovo has become an international precedent, Russia should take into account the Kosovo scenario...when considering ongoing territorial conflicts." ${ }^{\prime 20}$ Contrary to these assertions, the United States State Department has consistently claimed that Kosovo is sui generis, implying that no other secessionist movements could ever rely on this precedent. ${ }^{121}$ This article argues that the situations in Kosovo and Georgia have one major difference: the degree of involvement by the international community. Whereas in Kosovo, such involvement allowed for the transition toward independence, in Georgia no such assistance was offered to the South Ossetians and Abkhazians. This article also argues that the international community's stance toward Kosovo and Georgia, and its different levels of involvement in the two countries, seem more dictated by politics than by international law. ${ }^{122}$

Scholars have argued that Kosovo, because of the particular nature of the conflict, deserves independence, unlike the South Ossetians and the Abkhazians. ${ }^{123}$ Some scholars in particular have advanced the idea of earned sovereignty, a conflict resolution theory which posits that independence-seeking entities must, as a first step, share sovereignty with their mother States. ${ }^{124}$ According to this theory, such entities must first prove to the outside world that they are capable of functioning as an independent actor, before they will accrue the right to seek independence. ${ }^{125}$ Thus, Kosovo may be an example of an entity that first shared sovereignty with Serbia, under the Rambouillet Peace Plan and UN Resolution 1244, and that was able to subsequently demonstrate its capacity to function independently and to achieve statehood. ${ }^{126}$ International organizations play a significant role in the earned sovereignty model, by brokering deals which allow for shared sovereignty between the mother State and

120 UNOMIG, 'Recognition may come "this year," South Ossetia leader says -report', 21 February 2008.

121 Condoleeza Rice, US Secretary of State in 2008, argued immediately after the United States recognised Kosovo as a new State that Kosvo was sui generis. See 'Serbia Steps Up Anti-Kosovo Pressure', Austin News, 8 February 2008, <www.nbcaustin.com/ Global/story.asp?s=7889772> (arguing that the "unusual combination of factors found in the Kosovo situation - including the context of Yugoslavia's breakup, the history of ethnic cleansing and crimes against civilians in Kosovo, and the extended period of U.N. administration - are not found elsewhere and therefore make Kosovo a special case").

122 For another scholarly view that the situations in Kosovo and South Ossetia and Abkhazia should have been treated more similarly under international law, see Dubinsky, supra note 104.

123 See e.g. Gruda, supra note 31, at p. 353.

124 See generally J. R. Hooper and P. R. Williams, 'Earned Sovereignty: The Political Dimension', 31 Denv. J. Int'l L. \& Pol'y (2003) p. 355.

125 The theory of earned sovereignty consists of six elements. The first three core elements include shared sovereignty, institution building, and final status determination of the break-away entity, and the latter three elements are optional and include phased sovereignty, conditional sovereignty, and constrained sovereignty. See ibid., at p. 356.

126 See supra Part 3. 
the secessionist entity. In the case of Kosovo, the United Nations, NATO and the European Union have all been involved in this transition period..$^{127}$ The situation in Georgia has been different from Kosovo in this respect. While the international community has been involved in South Ossetia and Abkhazia, its role has been limited to peace keeping and negotiating peace agreements. ${ }^{128}$ The international community in Georgia has not contributed toward a plan of shared sovereignty, nor has it been preparing South Ossetians and Abkhazians to assume independent decision-making. Rather, the stance of most international entities has been to engage in peacekeeping and to emphasize the sovereignty and territorial integrity of Georgia. ${ }^{129}$ If the international community is unwilling to facilitate a plan of shared sovereignty between the mother State and the secessionist entity (and often, such "facilitation" involves significant diplomatic, financial and military pressure on the mother State), then the latter may never be able to fulfil the criteria of the above-mentioned earned sovereignty theory.

Even outside of the paradigms of this theory, the simple reality may be such that the secessionist entity may never be able to gather enough political and military strength to exercise independence de facto from the mother State. Thus, without significant international involvement, most secessionist struggles will remain unsuccessful. ${ }^{130}$ Unfortunately, international involvement in a separatist movement often has more to do with politics than the law, and the examples of Kosovo and Georgia underscore this point. Kosovo engaged in a separatist struggle against Serbia, a country ruled by a rogue leader (Slobodan Milosevic) and labelled as the culprit in the civil war in the 1990s in the former Yugoslavia. ${ }^{131}$ Until recently, Serbia has had very few allies on the international scene. The Kosovars, on the other hand, were able to gather the support of the international community, by emphasizing the politically unattractive image of Serbian leadership, by appealing to international scholars and human rights advocates, and by demonstrating that their potential independence would not disturb the geo-political equilibrium of the region. In fact, Kosovo's separation fragmented Serbian territory and presumably undermined the stability of

127 See supra Part 3 (detailing the involvement of NATO, the United Nations, and KFOR, a European Union peacekeeping military operation, in Kosovo).

128 See supra Part 4.

129 Ibid.

$130 \mathrm{I}$, and other scholars, have written about the development of a theory of the Great Powers' Rule, a phenomenon whereby the most powerful nations in the world (United States, United Kingdom, France, Italy, Germany, Japan, Russia and China) exert considerable influence on the international scene and often determine the outcomes of issues such as secessionist struggles. See e.g. M. J. Kelly, 'Pulling at the Threads of Westphalia: "Involuntary Sovereignty Waiver"? Revolutionary International Legal Theory of Return to Rule by the Great Powers?', 10 UCLA J. Int'l L. and Foreign Aff. (2005) p. 361; Sterio, supra note 112.

131 See supra Part 3. 
Serbia, an outcome that, in light of Milosevic's unpopularity in the Western world, seemed attractive, if not desirable.

The South Ossetians and the Abkhazians have faced a different situation. They are seeking to separate from Georgia, a country which has been largely supported by the Western leaders and which has been viewed as potential NATO ally in the Caucasus region. ${ }^{132}$ Thus, disturbing the stability and territorial integrity of Georgia, a country perceived as crucial to Western democracies because of its geographic location and its role as a regional counter-weight against Russia, is an undesirable outcome for most of the Western European democracies. The fact that South Ossetia and Abkhazia are supported by Russia contributes even further to the Western unwillingness to support these provinces' secessionist struggles. ${ }^{133}$ Most of the western world has feared the proliferation of Russian influence in the Caucasus; if South Ossetia and Abkhazia were to gain independence from Georgia, there is a strong possibility that they would become puppet States controlled by Russia. ${ }^{134}$ Despite the fact that these provinces function de facto independently from Georgia, the international community views this result as politically more desirable than if these provinces obtained independence and were freely able to officially align with Russia. International politics, as opposed to law, has played an enormous role in South Ossetia and Abkhazia, which as of now stand little chance of legally separating from Georgia. ${ }^{135}$ This Article argues that their cases may not be legally different from the case of Kosovo.

\subsection{Reconciling Territoriality with Minority Rights: $A$ Proposed Solution}

The examples of Kosovo and Georgia, where the notion of territorial integrity of the mother State collided with the need to respect minority rights, illustrate different approaches toward reconciling these two opposing principles. This article argues that legally the two cases are not entirely distinct and could be reconciled through the

132 Sterio, supra note 112 , at p. 174.

133 Ibid., at pp. 168-176 (discussing the various influences that the Great Powers have had on secessionist struggles, including the one in Georgia).

134 Some reports indicate that Russia has been seeking to annex South Ossetia and Abkhazia, thereby claiming for itself, against Georgia, a part of the Caucusus territory. See e.g. T. Helpin, 'Kremlin announces that South Ossetia will join "one united Russian state", 30 August 2008, available at <www.timesonline.co.uk/tol/news/world/europe/ article4635843.ece> (last visited on 3 May 32011) (noting Moscow's attempts to effectively annex South Ossetia following the 2008 war in Georgia); B. Whitmore, 'Abkhazia and the Perils of "Independence", 3 May 2011, available at <www.rferl.org/content/ Abkhazia_The_Perils_Of_Independence/1758008.html $>$ (last visited on 3 May 2011) (noting fears by Abkhazians that Russia may be effectively colonising Abkhazia).

135 See Dubinsky, supra note 104, at p. 246 ("The sizeable gap between practice and theory of international law on the right to self-determination in the post-Soviet sphere is likely to come into starker relief in the wake of Russia's recognition of South Ossetia and Abkhazia."). 


\section{Milena Sterio}

development of a theory which would resolve situations where territoriality is at odds with minority rights. In fact, the cases of Kosovo and Georgia have produced different results because of the different political realities surrounding these two regions. ${ }^{136}$

This article argues that the principle of territorial integrity may not be truly at odds with minority rights. I agree with scholars who have argued that secessionist movements almost always embrace a claim to territory which tends to be based on a historical grievance. ${ }^{137}$ The idea of self-determination, often applied toward resolving secessionist claims, focuses on the people, and not on territory. However, a self-determination claim relying on remedial secession inherently asserts a claim to territory. As Lea Brilmayer has argued, "[w] hat are characterized as self-determination claims are instead sometimes simple territorial disputes". ${ }^{138}$ Moreover, "[a] theory of secession necessarily depends upon a theory of legitimate sovereignty over territory". ${ }^{139}$ Thus, minority rights in the form of a secessionist claim are in fact compatible with the principle of territorial integrity as they are both about territory. The difficult question is how, and whether, to redraw boundaries to satisfy both the mother State and the secessionist entity. Scholars have already announced principles of reconciliation, which may be helpful in the context of Kosovo and Georgia. ${ }^{140}$

First, as most secessionist claims tend to be based on the perception of some historical grievance, where the mother State took over the land from the minority group at some point in the past, the key inquiry should be whether the status quo should be altered to rectify the past wrongdoing. ${ }^{141}$ This is an important, and difficult, issue. The secessionist minority may recognize itself that an even earlier historical wrong may have occurred, and that the remedy for the earlier wrong may nullify the present secessionist claim. Moreover, the secessionist minority may admit that the status quo is important as it prevents complete anarchy from occurring, and that it (the secessionist minority) may have in the present occupied the disputed territory wrongfully. "Hardly a territorial boundary anywhere in the world would survive an effort to correct all historical misdeeds. If protecting the status quo must be balanced against rectifying past injustices, then the obvious question is how much weight to assign each concern."142 Thus, in determining whether to rectify a historical wrong, one factor may be the immediacy of the historical claim. The closer in the past that the historical grievance can be situated, the more likely it is that the wrong should be remedied. Another factor may be the degree to which the secessionist group has

136 Other scholars would agree with me on this point. See e.g. Dubinsky, supra note 104, at p. 246 ("why Kosovo, but not Abkhazia and South Ossetia ... has a unique claim to independence is in the eye of the beholder.").

137 See e.g. Brilmayer, supra note 1.

138 Ibid., at p. 193.

139 Ibid., at p. 199.

140 See generally, Brilmayer, supra note 1.

141 Ibid., at p. 199

142 Ibid. 
managed to hold on to its claim..$^{143}$ If a minority group has always claimed that it was illegitimately annexed by the mother State, then the argument can be made that it never agreed to the loss of its territory. Thus, it may make sense to allow it to secede and reacquire its territory. Yet another factor may be whether the disputed territory is settled predominantly by the people belonging to the secessionist minority, or if the mother State has also moved its own natives to the disputed territory. ${ }^{144}$ The more mixed the population is in the disputed territory, the better the argument for the preservation of status quo. Finally, an important factor may be the nature of the historical grievance - the more heinous the historical wrongdoing toward the minority group, the better the argument that the group should separate from the mother State. ${ }^{145}$

None of these factors are easy to apply, but at least they point us toward the relevant inquiry of what amounts to a good secessionist claim, justifying the disruption of the mother State's territorial integrity.

\begin{abstract}
When a group seeks to secede, it is claiming a right to a particular piece of land, and one must necessarily inquire into why it is entitled to that particular piece of land, as opposed to some other piece of land - or no land at all.....When individuals seek to secede, they are making a claim to territory....Their claim is typically centered on a piece of land that they possessed in the past, and upon which they claimed territorial integrity. Territorial integrity properly understood accommodates the principle of self-determination. Whatever conflict exists is not between principles, but over land. ${ }^{146}$
\end{abstract}

The application of these principles of reconciliation between territoriality and minority rights to Kosovo and Georgia leads toward similar conclusions. First, both separatist groups in Kosovo and in Georgia have always claimed the right to territory, and have argued for remedial secession from their mother States. ${ }^{147}$ Thus, both of the conflicts are truly about territory, and less so about peoples. Second, both historical claims are directed toward remedying grievances from the same post-World War I era. The Kosovars were integrated into the territory of the newly created State of Yugoslavia after the break-up of Austria-Hungary in 1918, and the South Ossetians and Abkhazians became formally a part of Georgia after the creation of the Soviet Union and its annexation of Georgia in $1921 .{ }^{148}$ Third, all minority groups in question
143 Ibid., at p. 200.
144 Ibid.
145 Ibid.
146 Ibid., at p. 201.
147 See supra Parts 3 and 4.

148 See supra Part 3 for a history of Kosovo; for a detailed historical account on South Ossetia, see International Crisis Group, Georgia, 'Avoiding War in South Ossetia', 26 November 2004, available at <unpan1.un.org/intradoc/groups/public/documents/ UNTC/UNPAN019224.pdf $>$ (last visited on 3 May 2011); for a historical account on Abkhazia, see Conciliation Resources, 'Chronology (Georgia and Abkhazia)', available 
(the Kosovars, South Ossetians and Abkhazians) have always claimed to be different from their mother State, and have always asserted their right to secede. ${ }^{149}$ Because of oppressive political regimes existing in Serbia and the Soviet Union, such dissent was at times severely repressed. ${ }^{150}$ However, these minority groups have persevered in their claims for independent territory over the years. Fourth, in all three secessionist provinces, the minority group co-existed with citizens of the mother State for a number of years. ${ }^{151}$ With increasing conflict and secessionist violence, in all three cases non-ethnic Kosovars, South Ossetians and Abkhazians have been driven out so that all three provinces now are mainly inhabited with titular ethnicities..$^{152}$ Finally, in all three provinces, the historical grievance is of a similar nature. All three secessionist groups claim that territory was theirs at some point in the past, but was taken over by the mother State. Both mother States, Serbia and Georgia, have relied on different points in history to assert that these territories are legitimately theirs..$^{153}$ In all three secessionist provinces, wars and violence have occurred over the past two decades, and human rights violations have been committed on all sides. The situation in Georgia may be even more complex because of Russian involvement, and the fact that this conflict now involves not just the mother State and the minority groups, but also a very powerful outside actor seeking to exert influence over the seceding entities. ${ }^{154}$ The chart below examines the outlined criteria for secession for the two situations, in Kosovo and Georgia. The chart demonstrates that the criteria should lead toward the same result for all three separatist groups, either justifying secession for all, or denying it. The chart also demonstrates that the disparity in results which occurred de facto could not be legally explained.

at <www.c-r.org/our-work/accord/georgia-abkhazia/chronology.php> (last visited on 3 May 2011).

149 See supra Part 3; see also International Crisis Group, ibid:; see also Conciliation Resources, ibid.

150 Ibid.

151 Ibid.

152 Ibid.

153 Ibid.

154 See supra Part 4. 


\begin{tabular}{l|l|l|l|l}
$\begin{array}{l}\text { Separatist } \\
\text { Group/“People" }\end{array}$ & $\begin{array}{l}\text { Immediacy of } \\
\text { Historical Claim }\end{array}$ & $\begin{array}{l}\text { Has the People } \\
\text { Held on to its } \\
\text { Claim? }\end{array}$ & $\begin{array}{l}\text { Is Disputed } \\
\text { Territory Settled } \\
\text { Predominantly } \\
\text { by the People? }\end{array}$ & $\begin{array}{l}\text { Nature of His- } \\
\text { torical Griev- } \\
\text { ance }\end{array}$ \\
\hline $\begin{array}{l}\text { Kosovar Alba- } \\
\text { nians }\end{array}$ & Post World War I & Yes & Yes & $\begin{array}{l}\text { Alleged human } \\
\text { rights abuses } \\
\text { by mother State } \\
\text { (Serbia) }\end{array}$ \\
\hline South Ossetians & Post World War I & Yes & Yes & $\begin{array}{l}\text { Alleged military } \\
\text { involvement and } \\
\text { some abuses by } \\
\text { mother State } \\
\text { (Georgia) }\end{array}$ \\
\hline Abkhazians & Post World War I & Yes & & $\begin{array}{l}\text { Alleged military } \\
\text { involvement and } \\
\text { some abuses by } \\
\text { mother State } \\
\text { (Georgia) }\end{array}$ \\
& & & Yes &
\end{tabular}

Thus, any conclusions over how to reconcile territoriality and minority rights in Kosovo and Georgia are difficult to draw. Yet, any such conclusions should be similar because of similarity inherent in the secessionist claims existing in these regions. As this paper has argued, solutions for Kosovo and Georgia have been vastly different; the difference cannot be justified in law, only in international politics. The difference in political status of the mother States, Serbia and Georgia, has led toward, respectively, the secession and recognition of Kosovo as a new State, and the official maintenance of status quo with respect to South Ossetia and Abkhazia. This is an unfortunate result. Instead of turning to politics, the international community should look toward law for guidance. The above enumerated factors, which could be applied in assessing the validity of a self-determination claim, would be a useful tool to politicians, judges and scholars faced with the question of reconciling territoriality and minority rights in a given region.

\section{Conclusion}

As Lea Brilmayer has argued, the issue in the debate of territoriality versus minority rights "is not a relationship between peoples and states, but a relationship between people, states, and territory". ${ }^{155}$ The notion of self-determination is not simply about a people, rather, in most cases, it is about land. Reconciling the territorial integrity of a mother State with the territorial claim of a secessionist minority group entails asking difficult questions about whether the status quo should be altered. This article outlines relevant factors which the international community could rely upon when examining this question and when determining the legitimacy of future secessionist claims. This article also concludes that the cases of Kosovo and Georgia illustrate

155 Brilmayer, supra note 1, at p. 179. 


\section{Milena Sterio}

situations of similar conflicts, where the application of legal criteria would have led to similar results, but where, instead, reliance on international politics has produced opposing outcomes. The law would have been a better guide. 


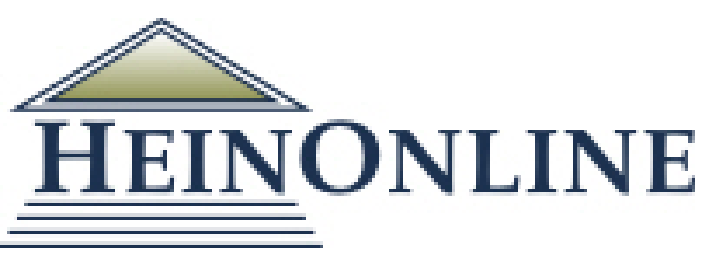

Content downloaded/printed from

HeinOnline

Tue Oct 29 12:06:18 2019

Citations:

Bluebook 20th ed.

Milena Sterio, Tale of Two States: Territoriality and Minority Rights in Kosovo and Georgia, A, 12 Baltic Y.B. Int'l L. 103 (2012).

ALWD 6th ed.

Milena Sterio, Tale of Two States: Territoriality and Minority Rights in Kosovo and Georgia, A, 12 Baltic Y.B. Int'l L. 103 (2012).

APA 6th ed.

Sterio, M. (2012). Tale of Two States: Territoriality and Minority Rights in Kosovo and Georgia, A. Baltic Yearbook of International Law, 12, 103-130.

Chicago 7th ed.

Milena Sterio, "Tale of Two States: Territoriality and Minority Rights in Kosovo and Georgia, A," Baltic Yearbook of International Law 12 (2012): 103-130

McGill Guide 9th ed.

Milena Sterio, "Tale of Two States: Territoriality and Minority Rights in Kosovo and Georgia, A" (2012) 12 Baltic YB of Intl L 103.

MLA 8th ed.

Sterio, Milena. "Tale of Two States: Territoriality and Minority Rights in Kosovo and Georgia, A." Baltic Yearbook of International Law, 12, 2012, p. 103-130. HeinOnline.

OSCOLA 4th ed.

Milena Sterio, 'Tale of Two States: Territoriality and Minority Rights in Kosovo and Georgia, A' (2012) 12 Baltic YB Int'I L 103

Provided by:

Cleveland-Marshall College of Law Library

-- Your use of this HeinOnline PDF indicates your acceptance of HeinOnline's Terms and Conditions of the license agreement available at https://heinonline.org/HOL/License

-- The search text of this PDF is generated from uncorrected OCR text.

-- To obtain permission to use this article beyond the scope of your license, please use: Copyright Information

Use QR Code reader to send PDF to your smartphone or tablet device

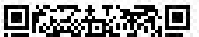

